\title{
PENINGKATAN PRODUKTIVITAS LAHAN PEKARANGAN MELALUI PEMANFAATAN SAMPAH RUMAH TANGGA SEBAGAI PUPUK ORGANIK DI DESA LANTAPAN KECAMATAN GALANG KABUPATEN TOLITOLI
}

\author{
Salawati $^{1 *}$, Nur Hikmah ${ }^{1}$, Nurmala $^{1}$, Yulianti Rasud $^{2}$, Sjarifuddin Ende $^{2}$, dan Henrik $^{3}$ \\ ${ }^{1}$ Program StudiAgribisnis Sekolah Tinggi Ilmu Pertanian Mujahidin Tolitoli \\ ${ }^{2}$ Program Studi Agroteknologi Sekolah Tinggi Ilmu Pertanian Mujahidin Tolitoli \\ ${ }^{3}$ Program Studi Peternakan Sekolah Tinggi Ilmu Pertanian Mujahidin Tolitoli \\ Jl. Dr. Samratulangi No. 51 Tuweley Tolitoli Sulawesi Tengah \\ Email: salawati@gmail.com
}

\begin{abstract}
ABSTRAK
Lahan pekarangan di desa Lantapan Kecamatan Galang Kabupaten Tolitoli cukup luas tetapi belum termanfaatkan secara efisien, Demikian halnya dengan sampah organik rumah tangga masyarakat yang di buang begitu saja berpotensi mencemari lingkungan. Pengabdian ini bertujuan meningkatkan produktivitas lahan pekarangan melalui pemanfaatan sampah rumah tangga dalam pembuatan pupuk organik cair pada kelompok ibu-ibu rumah tangga, melalui penyuluhan dan demo pembuatan pupuk organik cair berbahan dasar limbah rumah tangga. Program ini diawali dengan penyuluhan pemanfaatan pekarangan, selanjutnya demo pembuatan pupuk organik cair dan aplikasi pada tanaman sayuran di pekarangan. Hasil yang dicapai meningkatnya semangat ibu-ibu PKK dalam memanfaatkan pekarangan dan mengolah limbah organik rumah tangga menjadi pupuk organik cair.
\end{abstract}

Kata kunci: Limbah Rumah Tangga, POC, Sayuran

\section{Pendahuluan}

Permasalahan lingkungan sebagai akibat rendahnya kesadaran masyarakat terhadap pentingnya pengelolaan lingkungan. Berdampak pada pencemaran lingkungan pekarangan yang dihasilkan oleh adanya sampah (Khotimah, dkk. 2013). Pekarangan adalah lahan terbuka yang terdapat di sekitar rumah tinggal. Pekarangan memiliki sejumlah peran dalam kehidupan sosial ekonomi rumah tangga petani (Ashari, dkk., 2012). Jika dikelola dengan baik memberikan dampak positif/manfaat terhadap kehidupan keluarga selain itu dapat memberikan keuntungan ekonomi (meningkatkan pendapatan), memberikan nilai tambah bagi kehidupan rumah tangga itu sendiri (Khomah dan Fajarningsih, 2018).

Sampah merupakan salah satu permasalahan lingkungan yang memerlukan penanganan serius karena setiap aktivitas manusia pasti menghasilkan buangan/sampah yang jumlah dan volumenya sebanding dengan tingkat konsumsi masyarakat (Dhidhik, dkk. 2015). Pengelolaan sampah masih didominasi pada sistem pengumpulan sampah, pengangkutan sampah, dan pembuangan ke Tempat Pemrosesan Akhir (TPA) atau bertumpu pada pendekatan akhir (end-of-pipe). Pengelolaan sampah masih kurang mendapat penanganan yang optimal dari berbagai pihak, baik dari masyarakat setempat maupun pemerintah daerah (Khotimah, dkk. 2013).

Sebagai salah satu bentuk tanggung jawab perguruan tinggi dalam melaksanakan tridarma perguruan tinggi memberikan penyuluhan dan pelatihan pengelolaan sampah rumah tangga dengan cara sederhana, yaitu pembuatan Mikroorganisme Lokal (MOL) yang dapat dimanfaatkan sebagai pupuk untuk tanaman untuk meningkatkan produktivitas lahan pekarangan. Program penyuluhan dan pelatihan ini diharapkan sampah rumah tangga selanjutnya dapat dijadikan pupuk cair yang dapat menyuburkan tanaman bahkan dapat dijual kepada konsumen yang membutuhkan, sehingga akan memberikan penghasilan atau dapat menambah pendapatan 
rumah tangga masyarakat di Desa Lantapan Kecamatan Galang Kabupaten Tolitoli.

\section{Metode Pelaksanaan \\ Waktu dan tempat}

Kegiatan pengabdian ini dilaksanakan pada Februari s/d April 2019. Di desa Lantapan kecamatan Galang Kabupaten Tolitoli, pada kelompok ibu-ibu rumah tangga.

\section{Metode Pelaksanaan}

Kegiatan ini dilaksanakan dalam 2 tahap, tahap pertama penyuluhan manfaat limbah rumah tangga organik dan pelatihan pembuatan POC berbahan dasar sampah organik rumah tangga, tahap ke dua pendampingan budiaya sayuran hingga panen.

\section{Penyuluhan}

Pengetahuan ibu ibu tentang manfaat sampah yang diolah menjadi pupuk serta dampak sampah yang dibuang di pekarangan terhadap lingkungan ditingkatkan melalui penyuluhan, diskusi tatap muka langsung, dilakukan secara berkala selama program pengabdian berlangsung.

Untuk meningkatkan keterampilan dalam pembuatan pupuk organik cair berbahan dasar sampah rumah tangga terhadap ibu-ibu PKK diberi pelatihan, dan kunjungan langsung ke rumah warga masyarakat. Selama kegiatan penyuluhan dan pelatihan anggota kelompok menyiapkan material berupa sampah organik rumah tangga. Semua kebutuhan pelatihan disiapkan sepenuhnya oleh ibu ibu warga masyarak Desa Lantapan.

Pendampingan budidaya sayuran menggunakan pupuk organik cair (POC) yang dibuat sendiri didampingi mulai dari persiapan lahan hingga panen.

\section{Modul Pelatihan Pembuatan Pupuk Organik Cair (POC) berbahan dasar limbah rumah tangga.}

Peranan pupuk Organik berbahan dasar sampah (Rumah tangga dan, limbah pertanian) antara Lain :

1. Sumber nutirisi bagi tanaman bilah diolah lebih lanjut

2. Memperbaiki struktur tanah, menyediakan unsur hara, memperbaiki kehidupan mikroorganisme tanah, Lehmann 2007; Gani 2009).

3. Meretensi hara

4. Meningkatkan daya Sanggah tanah

5. Meningkatkan Ketersediaan nutrisi bagi tanaman (Salawati dkk., 2016; Salawati dan Ende 2019).

6. Menambah unsur hara yang tersedia bagi tanaman yang bersifat Slow Release Nutrient (SRN)

7. Meningkatkan daya tahan tanaman terhadap hama penyakit meningkatkan kualitas hasil panen

\section{Ringkasan Materi Penyuluhan}

Menurut Undang-Undang Republik Indonesia Nomor 18 Tahun 2008 tentang pengelolaan sampah, sampah didefinisikan sebagai sisa kegiatan sehari-hari manusia dan/atau proses alam yang berbentuk padat. Secara umum sampah dapat diklasifikasikan menjadi 2 yaitu sampah organik dan sampah anorganik. Sampah organik adalah sampah yang dapat terurai atau membusuk secara alamiah, misalnya sisa sayur-sayuran, buahbuahan, dan daun-daunan. Sampah ini merupakan bagian yang terbesar dari sampah rumah tangga $( \pm 70 \%)$. Sedangkan Sampah anorganik adalah sampah yang tidak dapat terurai atau membusuk secara alamiah dan memerlukan waktu yang sangat lama sekali untuk terurai, misalnya kertas, plastik, kayukayuan, kaca, kain, logam, dan lain-lain (Khotimah dkk., 2013).

Mutu nutrisi makanan menjadi perhatian karena sangat berperan dalam kesehatan manusia, beberapa kandungan mineral yang kurang berdampak buruk bagi konsumen (Ratmini 2014), penggunaan pestisida yang tinggi dan tak terkendali juga penyumbang dampak buruk bagi kesehatan manusia karena meningkatkan asupan radikal bebas terhadap sumber makanan manusia 
yang menimbulkan penyakit degeneratif (Latief 2004), peningkatan mutu nutrisi bagi tanaman palawija difokuskan pada peningkatan peningkatan kandungan protein, Fe, dan Zn (WHO. 2002 dalam Barunawati $d k k ., 2013)$.

\section{Pendampingan Lapangan (1) Persiapan Lahan}

Bedengan dengan ukuran lebar 120 $\mathrm{cm}$ dan panjang sesuai dengan ukuran petak tanah. Tinggi bedeng $20-30 \mathrm{~cm}$ dengan jarak antar bedeng 30 cm.sedangkan panjangnya mengikuti kondisi lahan. Jarak antar bedengan $30 \mathrm{~cm}$. Bedengan membujur dari timur-barat untuk mendapatkan pencahayaan yang maksimal. Bedengan tanaman (sawi, kangkung, bayam) yang digunakan berukuran lebar 100-120 cm dan tinggi $30 \mathrm{~cm}$. Jarak baris dalam bedengan $15 \mathrm{~cm}$ dan jarak tanam dalam bedengan 10-15 cm. Benih kangkung dan bayam ditanam dalam alur dengan jarak 10 $\mathrm{cm}$ antar alur.

\section{(2) Penyemaian dan penanaman}

Persemaian tanaman sawi dilakukan di petak persemaian. Benih didapatkan dari toko saprodi, selanjutnya benih direndam selama 6 jam, benih yang mengapung dibuang, selanjutnya benih dikering anginkan menggunakan lapisan tisu,setelah itu benih disebar merata di petak persemaian, kondisi persemaian dalam keadaan lembab serta tidak terkena sinar matahari secara langsung.

Bibit sawi di tanaman dengan jarak baris dalam bedengan $15 \mathrm{~cm}$ dan jarak tanam dalam bedengan 10-15 cm. Benih kangkung dan bayam ditanam dalam alur dengan jarak $10 \mathrm{~cm}$ antar alur, benih ditanam secara langsung yang sebelumnya dirandam selama 15 menit menggunakan air hangat. Wadah persemaian tanaman sawi yang digunakan berupa wadah baki plastik, pot plastik, kotak dari kayu, kantong plastik, polybag dan bedengan persemaian. Tanah yang digunakan di ayak terlebih dahulu untuk menghindari bongkahan menggunakan saringan kawat berdiameter lubang $2-5 \mathrm{~mm}$.
Pembibitan di lakuan hanya untuk benih yang kecil dan mahal misalnya benih sawi, selada, cabai, tomat, (kecuali bayam dan kangkung ditanam langsung).

Langkah-langkah penanaman bibit atau benih

1. Buat lubang kecil pada media tanam di dalam dengan kedalaman 0,5-1 cm dengan menggunakan lidi atau kayu kecil. Untuk benih yang dibibitkan dalam wadah pembibitan yang lebar dilakukan dengan cara menebar secara merata benih pada permukaan media tanam atau membuat lubang tanam dengan jarak kurang lebih $1 \mathrm{~cm}$.

2. Benih dimasukkan ke dalam lubang tanam dan ditutup tanah/ kompos / pupuk kandang tipis.

3. Penyiraman dilakukan dengan hati hati dan merata agar tidak merusak media pembibitan. Penyiraman dilakukan 2 kali sehari pada saat benih baru ditanam atau bibit kecil, pada saat bibit tumbuh agak besar, penyiraman dilakukan sehari atau sesuai kondisi.

4. Wadah pembibitan diletakkan pada tempat yang terlindung dari deraan hujan secara langsung namun terkena sinar matahari cukup, (di bawah sungkup atau rumah plastik).

5. Setelah bibit memiliki daun sempurna 3-5 lembar, bibit dipindahkan pada wadah penanaman dan atau di bedengan.

Penanaman sawi di lakukan dengan Langkah-langkah sebagai berikut:

1. Pilih bibit yang sehat, tidak cacat, dan seragam

2. Buat lubang tanam, jarak tanam berkisar $10-15 \mathrm{~cm}$.

3. Masukkan bibit ke dalam lubang tanam, selanjutnya tutup lubang tanam menggunakan media tanam yang sebelumnya dikeluarkan pada saat membuat lubang tanam.

4. Lakukan penyiraman hingga media tanam menjadi basah secara merata. 
Abditani : Jurnal Pengabdian Masyarakat 3 (1) 44-49

e-ISSN : 2622-4690

p-ISSN : 2622-4682

\section{(2) Pemupukan}

Pemupukan dilakukan pada saat tanaman berumur 7 hari setelah tanam menggunakan pupuk POC yang dibuat sendiri, pemupukan dilakukan di pagi hari dengan cara di semperotkan pada tanaman, penyemprotan dilakukan setiap minggu.

\section{(3) Panen}

Tanaman sawi dipanen pada saat tanaman berumur 45 hingga 60 hari usai penanaman benih, tanaman sawi ditanam dengan cara mencabut tanaman, lalu dipotong pada pangkal batang. Sedangkan untuk tanaman kangkung dipanen pada saat tanaman berumur 30 -40 hari setelah tanam, pemanenan dilakukan dengan cara memotong tanaman, agar bisa dipanen berulang. Tanaman bayam dipanen pada saat tanaman berumur 21-30 hari setelah tanam, dengan cara mencabut tanaman.

\section{Hasil dan Pembahasan}

\section{Survey Potensi lahan yang belum termanfaatkan}

Pelaksanaan program pemanfaatan pekarangan dalam rangka peningkatan pendapatan rumah tangga, berdasarkan permintaan dari kepala desa Lantapan kecamatan Galang Kabupaten Tolitoli, menindak lanjuti perminataan ini LPPM STIP Mujahidin Tolitoli melakukan survey potensi lahan, peluang dan tantangan, pada beberapa sumber data antara lain, kepala desa, guru, Kelompok Tani, tokoh masyarakat, tokoh adat, ibu PKK sebagi sasaran pelaksana program. Data didapatkan melalui wawancara langsung, diskusi kelompok (Focus group discussion), survey dilaksanakan pada bulan Desember 2018. Sebelum program dilaksanakan. Beberapa informasi hasil survey yang dikumpulkan sebagai berikut:

1. Desa Lantapan merupakan tipologi Desa pertanian yang berbatasan dengan kota kabupaten, salahsatu lumbung padi kabupaten Tolitoli yang pekarangannya banyak yang tidak termafaatkan secara kontinyu.
2. Wadah utama dalam pelaksanaan program pemberdayaan ibu-ibu sudah ada seperti PKK, kelompok tani, KWT tetapi belum efektif dalam melaksanakan program.

3. Sampah rumah tangga di buang dipekarangan tanpa di olah berpotensi mencemari lingungan rumah tinggal dan pekarangan.

4. Ratarata warga memiliki pekarangan yang luas tetapi belum dimanfaatkan secara maksimal.

5. Jarak antara desa dengan pasar kurang lebih $3 \mathrm{~km}$.

\section{Lokakarya}

Lokakarya merupakan wadah memusyawarakan pengaktifan kembali lembaga yang telah terbentuk untuk melaksanakan program kerjanya dalam rangka mendukung peningkatan ekonomi rumah tangga dan kesehatan lingkungan. Lokakarya dilaksanakan pada bulan Februari tahun 2019 bertempat di aulah desa lantapan. Lokakarya menyajikan laporan hasil survey dan dimusyawarahkan bersama masayarakat dan lembaga formal yang ada di desa Lantapan (Kelompok Tani, KWT, PKK, Remaja Mesjid karang taruna). Lokakarya ini menghasilkan beberapa kesepakatan :

1. Sampah rumah tangga, limbah pertanian perlu diolah agar tidak mencemari lingkungan

2. Peserta lokakarya menetapkan ibu PKK yang akan melaksanakan pengolahan sampah rumah tangga

3. Kelompok tani mengolah limbah pertanian

4. Kegiatan di fokuskan pada pembuatan pupuk organik cair berbasis sampah rumah tangga

5. Pembuatan poschar untuk limbah pertanian dan ternak sapi, kambing dan ayam

6. Tidak ada pekarangan yang tidak di tanami, jika tidak sanggup mengolah pekarangan, maka wajib dipinjamkan kepada warga yang dapat mengolah pekarangan 
Abditani : Jurnal Pengabdian Masyarakat 3 (1) 44-49

7. Pekarangan di tanami sayuran dan rempah (seledri, sawi, bayam dan kangkung)

\section{Pertemuan rutin}

Pertemuan rutin dilaksanakan setiap bulan, di pusatkan di bali desa pada hari jumat pagi/sore disesuaikan kondisi setiap awal bulan berjalan.

1. Koordinator pemberdayaan keluarga mengolah sampah rumah tangga menjadi pupuk terpilih adalah Ny. Alibaba yang juga berprofesi sebagai guru biologi.

2. Program yang direncanakan selama 1 tahun adalah bidang pendidikan pembentukan taman baca, bidang kesehatan : peningkatan pelayanan posyandu, posbidu, poslansia, kesehatan reproduksi remaja dan narkoba. Bidang ekonomi pengolahan hasil pertanian (pembuatan krupuk), bidang lingkungan : pembuatan pupuk organik cair berbahan dasar limbah rumah tangga organik, pembuatan biochar sekam padi, pestisida organik. LPPM STIP fokus pada pendampingan pengolahan sampah rumah tangga, sementara progam lain belum difokuskan.

3. Balai desa disepakati sebagai pusat tempat pelaksanaan pemberdayaan keluarga. (pertemuan)

\section{Pelatihan dan pembekalan}

Kegiatan pengembangan pemberdayaan keluarga, diawali dengan pelatihan pembekalan bagi ibu di laksanakan di balai desa Lantapan, untuk meningkatkan motivasi masyarakat materi difokuskan pada motivasi memberdayakan keluargan dalam mengolah sampah, serta teknik penyusunan program. Output dari pelatihan ini adalah munculnya motivasi yang tinggi dari peserta pemberdayaan keluarga, teknik budidaya sayuran. Selanjutnya pelatihan pembuatan pupuk organikcair berbasis sampah rumah tangga dilaksanakan di aula balai desa Lantapan output dari kegiatan pelatihan ini adalah peserta trampil dalam membuat pupuk organik cair, pestisida organik, dan poschar.

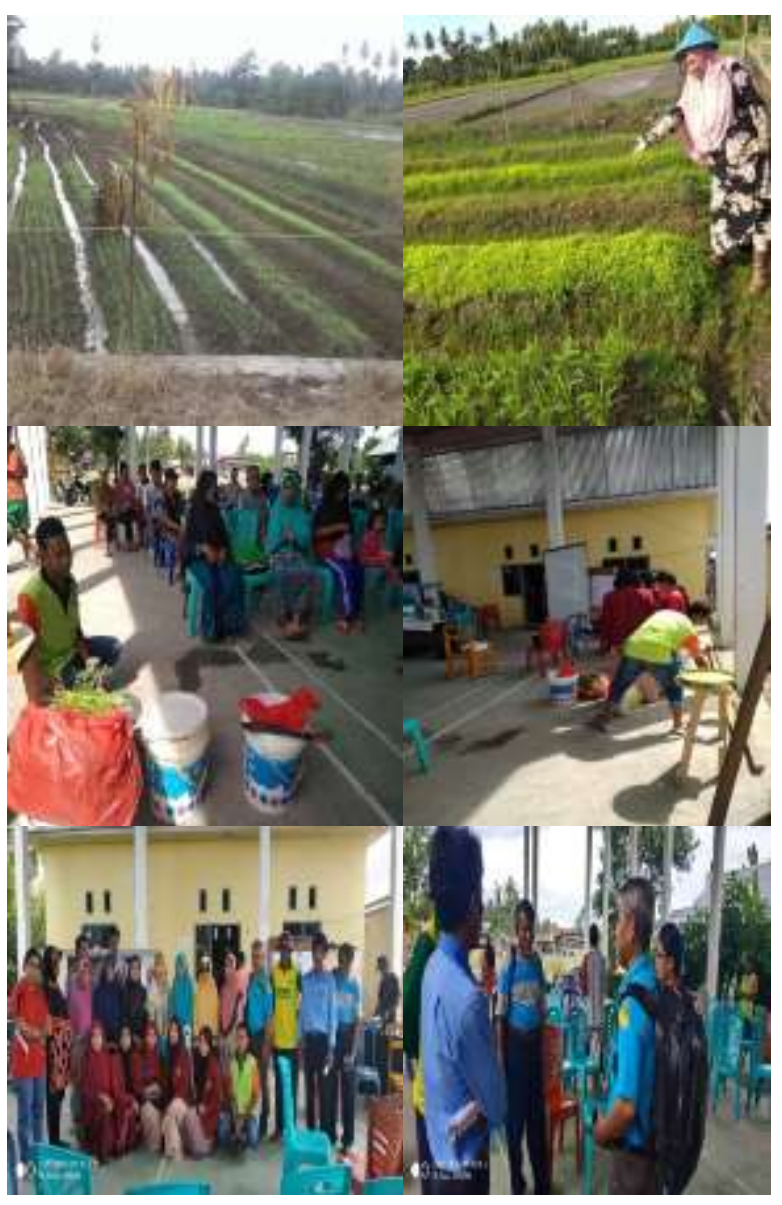

Gambar 1. Kegiatan pelatihan

\section{Pendampingan}

Pendampingan pemberdayaan keluarga dalam memanfaatkan limbah rumah tangga dimaksudkan untuk memotivasi warga (Ibu PKK) dalam mewujudkan rencana kerjanya. Salahsatu upaya agar Ibu PKK tetap semangat melaksankan program melalui pertemuan rutin setiap bulan. Pendampingan sangat berperan sebagi patner ibu PKK dalam melaksanakan programnya.

\section{Kesimpulan}

1. Pengolahan sampah organik rumah tangga dapat mengurangi cemaran sampah di pekarangan

2. Penggunaan pupuk organik berbahan dasar limbah rumah tangga dapat menyehatkan tanah serta meningkatkan kesuburan tanah dengan biaya yang relatif murah

3. Meningkatkan nilai tambah gizi bagi keluarga 
4. Menekan biaya pembelian sayur bagi keuangan rumah tangga

\section{Daftar Pustaka}

Ashari, Saptana dan T. B. Purwantini. 2012. Potensi dan Prospek Pemanfaatan Lahan Pekarangan Untuk Mendukung Ketahanan Pangan. Jambi. Forum Penelitian Agro Ekonomi, 30(1) : 13-30.

Barunawati, N., Murdiono, W. E., Armita, D., \& Karyawati, A. S. (2013). Upaya Memperbaiki Kualitas Hasil Panen Tanaman Gandum Melalui Aplikasi Citra Sebagai Khelator Unsur Mikro. Prosiding Seminar Nasional 3 in ONE, (21 Agustus 2013). Malang

Dhidhik, H., Rinawidyastuti, F. Iskandar dan N. Maharani. 2015. Pengolahan sampah organik menjadi pupuk organik Desa Kalegen Kecamatan Bandongan Kabupaten Magelang. Magelang. Universitas Muhammadiyah Purwerejo.

Gani, A. (2009). Potensi Arang Hayati “ Biochar" Sebagai Komponen Teknologi Perbaikan Produktivitas Lahan Pertanian. Iptek Tanaman Pangan, 4(1), 33-48. Retrieved from http://pangan.litbang.pertanian.go.id/files/0 3-anischan.pdf

Khomah, I dan R. U. Fajarningsih. 2019. Potensi dan Prospek Pemanfaatan Lahan Pekarangan Terhadap Pendapatan Rumah Tangga. Surakarta. Proceeding Seminar nasional, 155-161.

Khotimah, N., D. R. S. Sumunar., A. Sudarsono dan S. Setyawati. 2013. Pelatihan pengelolaan sampah rumah tangga dengan metode composting di Desa Banyurejo Kecamatan Tempel Kabupaten Sleman. Yogyakarta. Universitas Negeri Yogyakarta.

Lehmann, J. (2007). Bio-Energy in the Black. Frontiers in Ecology and the Environment, 5(7), 381-387. Retrieved from www.frontiersinelogy.org

Marliani, N. 2014. Pemanfaatan Limbah Rumah Tangga (Sampak Anorganik) Sebagai bentuk
Implementasi dari Pendidikan Lingkungan Hidup. Jakarta. Jurnal Formatif, 4(2) : 124132.

Novitasari, E. 2011. Studi Budaya Tanaman Pangan di Pekarangan Sebagai Sumber Ketahanan Pangan Keluarga (Studi Kasus di Desa Ampel Gading Kecamatan Tirtoyudo Kabupaten Malang. Malang. Skripsi di terbitkan. Universitas Brawijaya Malang.

Rahayu, M dan S. Prawiroatmodjo. 2005. Keanekaragaman Tanaman Pekarangan dan Pemanfaatannya di Desa Lampeapi Pulau wanoni Sulawesi Tenggara. J. Tek. Ling P3TL-BPPT, 6(2) : 360-364.

Ratmini, N. P. S. (2014). Peluang Peningkatan Kadar Seng (Zn) Pada Produk Tanaman Serealia. Prosiding Seminar Nasional Lahan Suboptimal, (26-27 September), 674-684. Palembang.

Rauf, Rahmawati dan D. B.T. J Said. 2013. Sistem Pertanian Terpadu di Lahan Pekarangan Mendukung Ketahanan Pangan Berkelanjutan dan Berwawasan Lingkungan. Jurnal online Pertanian Tropik Pascasarjana FP USU, 1 (1). http://jurnal.usu.ac.id/index.php/tropik/article /download/4663/2485 [09/01/2019].

Salawati, Basir, M., Kadekoh, I., \& Thaha, A. R. (2016). Potensi Biochar Sekam Padi Terhadap Perubahan $\mathrm{pH}, \mathrm{KTK}, \mathrm{C}$ Organik dan $\mathrm{P}$ Tersedia Pada Tanah Sawah Inceptisol. Agroland, 23(2), 101-109.

Salawati and Sjarifuddin Ende, 2019. The Use of Rice Husk Biochar and Flooding System on Rice Production In Central of Sulawesi Indonesia. IJSBAR, 48 (5):185-195.

Subandar, I., D. Nurba., dan A. Gafur. 2015. Peningkatan Produktivitas Lahan Melalui Pemanfaatan Lahan Pekarangan Di Meureubo Kabupaten Aceh Barat. Aceh. Jurnal Agrotek Lestari, 1 (1) : 21-26

Suwarto. 2008. Produktivitas Lahan dan Biaya Usahatani Tanaman Pangan di Kabupaten Gunung Kidul. Surakarta. Jurnal Ekonomi Pembangunan, 9 (2) : 168-183. 